\title{
Cannabinoids and Dopamine Receptors' Action on Calcium Current in Rat Neurons
}

\author{
C. Vásquez, R. Navarro-Polanco, G. Hernández, J. Ruiz, D.G. Guerra, \\ L.M. Baltazar, M. Huerta, X. Trujillo
}

\begin{abstract}
Objective: To study the effects of cannabinoid, glutamate, and dopamine agonists and antagonists on the calcium current in rat sympathetic neurons. Methods: Calcium current was recorded using the whole-cell variant of the patch-clamp technique. After expression in neuronal membranes of the cannabinoid CB1, glutamate mGluR2, or dopamine D1 receptor (by microinjection of the relevant receptor's cDNA into the neuron's nucleus) agonists' and antagonists' effects were observed. Results: Applications of agonists of the expressed receptor $(0.1-10 \mu \mathrm{M})$ decreased the calcium current. The calcium current was increased after application of cannabinoid antagonists (AM251 and AM630); these compounds thus act as inverse agonists in this preparation. Glutamate and dopamine antagonists had no effects on the calcium current by themselves. Combined application of cannabinoids and dopamine, but not glutamate, agonists produced a decrement in the calcium current that was bigger than either of the effects seen when one agonist was applied alone. Conclusions: These results suggest that cannabinoid with dopamine receptors have an interactive inhibitory effect on the calcium current in this preparation, indicating that within the nervous system, receptor interactions may be important in the regulation of ion-channel functions.
\end{abstract}

RÉSUMÉ: Effet des cannabinoïdes et des récepteurs dopaminergiques sur les courants calciques dans des neurones de rat. Objectif: Étudier les effets d'agonistes et d'antagonistes de cannabinoïdes, du glutamate et de la dopamine sur le courant calcique dans des neurones sympathiques de rat. Méthodes: Le courant calcique a été enregistré au moyen de la technique patch-clamp sur cellules intactes. Des effets agonistes et antagonistes ont été observés après expression dans les membranes neuronales du récepteur cannabinoïde de type CB1, du récepteur métabotropique du glutamate mGluR2 ou du récepteurs D1 de la dopamine par micro injection de l'ADNc correspondant au récepteur dans le noyau du neurone. Résultats: L'application d'agonistes du récepteur exprimé $(0,1$ à $10 \mathrm{mmol})$ diminuait le courant calcique. Le courant calcique était augmenté suite à l'application d'antagonistes cannabinoïdes tels l'AM251 et l'AM630. Ces substances agissent donc comme des agonistes inverses dans cette préparation. Les antagonistes du glutamate et de la dopamine n'avaient pas d'effet sur le courant calcique par eux-mêmes. Une application combinée d'agonistes de cannabinoïdes et de dopamine diminuait davantage le courant calcique que l'application de chacun d'eux seul, ce qui n'était pas le cas des agonistes du glutamate. Conclusions: Ces résultats suggèrent un effet inhibiteur interactif des récepteurs cannabinoïdes et des récepteurs dopaminergiques sur le courant calcique dans cette préparation. Ceci indique que, dans le système nerveux, l'interaction de récepteurs pourrait être importante dans la régulation des fonctions des canaux ioniques.

Can. J. Neurol. Sci. 2005; 32: 529-537

The brain CB1 cannabinoid receptor is a member of the Gprotein-coupled receptor superfamily. ${ }^{1}$ Among the wide variety of effects induced by activation of $\mathrm{CB} 1$ cannabinoid receptors are: inhibition of glutamatergic and $\mathrm{GABA}_{\mathrm{A}}$ synaptic transmission, ${ }^{2-4}$ inhibition of dopamine release in rat brain, ${ }^{5}$ and inhibition of serotonin release in mouse brain. ${ }^{6}$ Thus, the CB1 cannabinoid receptor modulates neuronal excitability and neurotransmitter release, and thereby regulates $\mathrm{Ca}^{2+}$ - and $\mathrm{K}^{+}$currents. ${ }^{7}$ Activation of $\mathrm{CB} 1$ receptors has been shown to inhibit $\mathrm{N}$ - and P-/Q-type $\mathrm{Ca}^{2+}$ channels in cultured hippocampal neurons and in heterologous expression systems..$^{8-9}$ On the other hand, $\mathrm{CB} 1$ receptors activate inwardly rectifying $\mathrm{K}+$ channels, ${ }^{10}$ and it was recently shown that cannabinoids decrease the $\mathrm{K}^{+} \mathrm{M}$-current in hippocampal CA1 neurons. ${ }^{11}$ Additionally, there is evidence for associations and signaling interactions between cannabinoids and both glutamate and dopamine receptors. ${ }^{12-16}$ However, to our knowledge such interactions have not been investigated at the ion-channel level. We now report that combined activation of D1 and $\mathrm{CB} 1$ receptors in rat sympathetic neurons results in a greater

From the Centro Universitario de Investigaciones Biomédicas, Universidad de Colima (CV, RNP, MH, XT), Colonia Villa de San Sebastián, Colima, Colima, C.P. 28040, México; Facultad de Enfermeria, Universidad de Colima (GH, JR, DGG), Facultad de Medicina, Universidad de Colima (LMB), Colonia Las Viboras, Colima, Colima, C.P. 28040, Mexico.

Received October 4, 2004. AcCePted IN FinAl Form June 3, 2005. Reprint requests to: Clemente Vásquez, Centro Universitario de Investigaciones Biomédicas, Avenida 25 de julio \# 965, Universidad de Colima, Colonia Villa de San Sebastián, Colima, Colima, C.P. 28040, México. 
$\mathrm{Ca}^{2+}$ current inhibition than that observed on activation of either receptor alone. These data seem to indicate a cooperative action on the $\mathrm{Ca}^{2+}$ current, and indicate that within the nervous system, receptor interactions may be important in the regulation of the function of ion channels.

\section{Materials AND Methods}

\section{Neuron Preparation}

Sympathetic neurons were isolated from the superior cervical ganglia (SCG) of adult male Wistar rats of five-six months of age (350-375g). All procedures were in accordance with the National Institutes of Health Guidelines for the Care and Use of Laboratory Animals in Research, and were approved by the Committee on Animal Use for Research and Education at the University of Colima. All efforts were made to minimize animal suffering and to use only the number of animals necessary to produce reliable scientific data. The ganglia were dissected in cold Hank's balanced salt solution, then incubated in a flask containing modified Earle's balanced salt solution with 0.9 $\mathrm{mg} / \mathrm{ml}$ collagenase type $\mathrm{D}, 0.3 \mathrm{mg} / \mathrm{ml}$ trypsin (both from Boehringer Mannheim), and $0.1 \mathrm{mg} / \mathrm{ml}$ DNase type I (Sigma Company, St. Louis, MO, USA.). This incubation, at $35^{\circ} \mathrm{C}$ for 1 hour, was conducted in a shaking water-bath. Cells were then dissociated by vigorous shaking of the flask by hand for $10 \mathrm{sec}$. Cells were washed with, and plated in, Minimum Essential Medium (Gibco, Invitrogen, USA) containing 10\% fetal bovine serum (Gibco, Invitrogen, USA), $1 \%$ penicillin/streptomycin, and $1 \%$ glutamine (both from Sigma) on poly-L-lysine-coated 35 $\mathrm{mm}$ culture dishes. Cells were then maintained at $37^{\circ} \mathrm{C}$ in a humidified atmosphere containing $5 \% \mathrm{CO}_{2}$, and allowed to attach for four-five hours before microinjection.

\section{Molecular biology and microinjection}

The cDNAs for the human CB1 cannabinoid receptor (hCB1), the metabotropic glutamate receptor 2 (mGluR2), and the dopamine receptor 1 (D1) were subcloned into the mammalian expression vector pCI (Invitrogen), hCB1 between the $\mathrm{XbaI}$ and $\mathrm{BamHI}$ restriction sites, mGluR2 between the SalI and NotI restriction sites, and D1 between the XbaI and EcoRI restriction sites. Preparation of plasmid DNAs was accomplished using a plasmid prep kit (Qiagen).

The nuclei of single SCG neurons were microinjected with pCI containing hCB1, mGluR2, and/or D1 cDNA (either separately or combined, as the experiment required). Plasmids were diluted with Tris/EDTA $\mathrm{pH} 8$ to a final injection concentration of $100 \mathrm{ng} / \mu \mathrm{l}$. The pEGFP-N1 plasmid $(10 \mathrm{ng} / \mu \mathrm{l})$ containing the cDNA encoding enhanced green fluorescent protein (Clontech, Palo Alto, CA, USA) was used as a coinjection marker. The plasmid solution was centrifuged $(16,000 \mathrm{Xg})$ in non-heparinized hematocrit tubes for 20 minutes to remove particles. Injection pipettes were made from fiberfilled capillary glass (1B100F-4; World Precision Instruments, Sarasota, FL, USA) pulled on a P-97 Flaming-Brown micropipette puller (Sutter Instrument Co., Novato, CA, USA). Nuclear microinjection was performed with the aid of an Eppendorf FemtoJet and 5171 micromanipulator (Eppendorf, Madison, WI, USA) using an injection pressure of $90-150 \mathrm{hPa}$ and an injection time of 0.4-0.6 seconds. The actual amount of DNA injected is unknown, but we estimated it to be of the order of $0.1 \mathrm{ng}$ per cell. Successful injections were subsequently confirmed by observing the cells for fluorescence on an inverted microscope (Olympus CK40) equipped with an epifluorescence unit (Figure 1).

\section{Electrophysiological recording of $\mathrm{Ca}^{2+}$ current}

$\mathrm{Ca}^{2+}$ currents from rat SCG neurons were recorded at room temperature $\left(22-24^{\circ} \mathrm{C}\right)$ some $16-20$ hours after microinjection using the whole-cell variant of the patch-clamp technique ${ }^{17}$ with the aid of an Axopatch 200B patch-clamp amplifier (Axon Instruments, Foster City, CA, USA). Patch electrode pipettes were made by pulling borosilicate glass capillaries (Corning 7052; Garner Glass Co., Claremont, CA, USA) on a P-97 Flaming-Brown micropipette puller (Sutter Instruments). The patch electrodes were coated with Sylgard 184 (Dow Corning Corp., Midland, MI, USA) and fire-polished on a microforge (Narishige, Tokyo, Japan). The cell membrane capacitance and
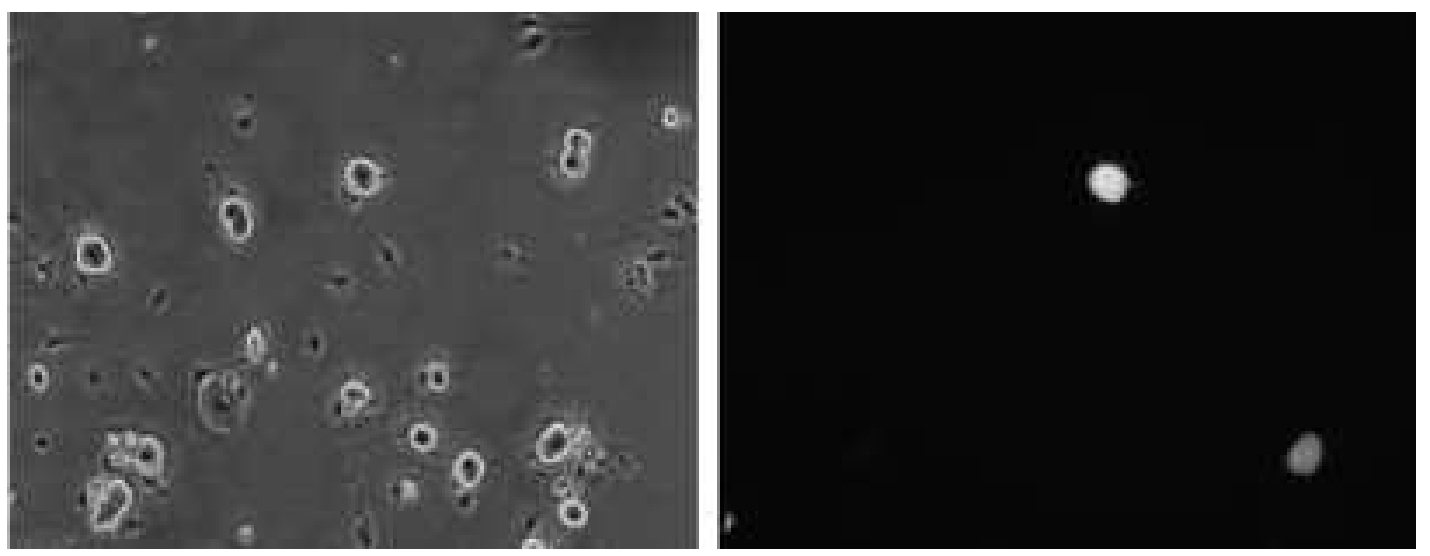

Figure 1: Microinjected superior cervical ganglion neurons. A) Phase contrast photomicrograph. B) Photomicrograph of the same field under fluorescence optics showing neurons successfully injected. Neurons are approximately 25-30 $\mu \mathrm{m}$ in diameter. 
series resistance were electronically compensated to $>80 \%$. Whole-cell currents were low-pass filtered at $5 \mathrm{kHz}(-3 \mathrm{~dB})$ using the 4-pole Bessel filter of the clamp amplifier. In addition, we applied suppression of capacitive transients and leak-subtraction protocols.

To isolate $\mathrm{Ca}^{2+}$ currents for whole-cell recording, cells were bathed in an external solution containing (in mM): 140 tetraethylammonium methanesulfonate, 10 HEPES, 15 glucose, $10 \mathrm{CaCl}_{2}, 0.0001$ tetrodotoxin, $\mathrm{pH} 7.4$ (adjusted with methanesulfonic acid). The intracellular solution consisted of (in $\mathrm{mM}$ ): $120 \mathrm{~N}$-methyl-D-glucamine, 20 tetraethylammonium chloride, 10 HEPES, 11 EGTA, $1 \mathrm{CaCl}_{2}, 4 \mathrm{MgATP}, 0.1 \mathrm{Na}_{2}$ GTP, 14 phosphocreatine, pH 7.2 (adjusted with methanesulfonic acid).

Voltage-clamp protocols were generated by a Compaq S500 computer (Pentium III) using the program pClamp 8.0 (Axon Instruments, Foster City, CA, USA). Data were digitized using a DIGIDATA 1200 interface (Axon Instruments, Foster City, CA, USA) and stored on the computer's hard disc. $\mathrm{Ca}^{2+}$ currents were elicited by voltage steps from a holding potential of $-80 \mathrm{mV}$ and

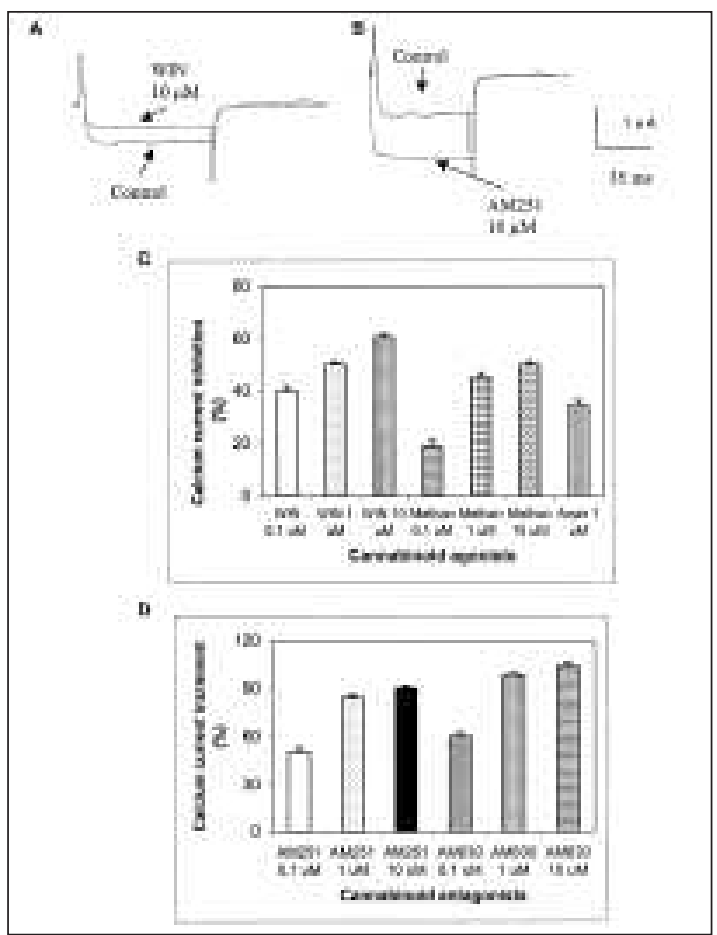

Figure 2: Effects of cannabinoid agonists and antagonists on $\mathrm{Ca}^{2+}$ current in sympathetic neurons. A) Superimposed traces of $\mathrm{Ca}^{2+}$ currents recorded from an SCG neuron in the absence (Control) and presence of WIN 55,212-2 (10 $\mu M$ WIN). Currents were induced by depolarizing voltage pulses from $-80 \mathrm{mV}$ to a test potential of $+5 \mathrm{mV} . \mathrm{B}$ ) Superimposed traces of $\mathrm{Ca}^{2+}$ currents from the same neuron in the absence (Control) and presence of AM251 (10 $\mu M$ AM251). C) Bar graph showing the $\mathrm{Ca}^{2+}$ current inhibitions induced by the concentrations used of WIN 55,212-2, methanandamide, and anandamide (cannabinoid agonists). D) Bar graph showing the increments in the $\mathrm{Ca}^{2+}$ current induced by the concentrations used of AM251 and AM630 (cannabinoid antagonists). All data are from SCG neurons microinjected with human cannabinoid receptor CB1 cDNA. digitized at $180 \mu \mathrm{sec} /$ point. A pulse-protocol consisting of one 50 ms step to $+5 \mathrm{mV}$ was used to elicit $\mathrm{Ca}^{2+}$ currents. Figures were generated using Clampfit (Axon Instruments, Foster City, CA, USA) with final preparation in Sigmaplot (SPSS Inc., Chicago, IL, USA).

Drug solutions were applied to isolated cells by bath perfusion. All compounds were diluted to their final concentrations in the external solution (from concentrated stock solution) just before use. Stock solutions (each, $10 \mathrm{mM}$ ), were made up as follows: WIN 55,212-2 mesylate, AM251 and AM630 (Tocris Cookson Inc., Ballwin, MO, USA) in dimethylsulfoxide; anandamide (Tocris Cookson Inc., Ballwin, MO, USA) and methanandamide (Research Biochemicals International, Natick, MA, USA) in ethanol; L-CCG-I, DCG-IV, (RS)-APICA, and EGLU in NaOH; dihydrexidine, SKF-38393, and $\mathrm{SCH}-23390$ in water. The final concentrations of dimethylsulfoxide, ethanol, and $\mathrm{NaOH}$ were $<0.01 \%$; none had any effect on the $\mathrm{Ca}^{2+}$-current. Stock solutions were stored at $-20^{\circ} \mathrm{C}$.

Statistical significance was determined by means of a Student's t-test or ANOVA test as indicated, differences being considered significant at $\mathrm{P}<0.05$. Results are presented as means \pm S.E.M.

\section{RESULTS}

\section{Effects of cannabinoid agonists and antagonists}

In the present study, the cannabinoid agonist WIN 55,212-2 significantly reduced the calcium current in neurons microinjected with hCB1 cDNA by $60.7 \pm 1.2(\mathrm{p}<0.0001)$, $50.2 \pm 0.9 \quad(\mathrm{p}<0.0001)$, and $40.1 \pm 1.7 \% \quad(\mathrm{p}<0.001)$ at concentrations of 10,1 , and $0.1 \mu \mathrm{M}$, respectively $(\mathrm{n}=3$ for each concentration) (Figure 2A and 2C). However, it had no effect in uninjected neurons. Anandamide $(1 \mu \mathrm{M})$ and methanandamide $(1 \mu \mathrm{M})$, endogenous cannabinoids, inhibited the calcium current too (Figure 2C). AM251, a cannabinoid antagonist, as well as blocking the effect of the WIN 55,212-2 (the corresponding values being $0.3 \pm 0.5(10 \mu \mathrm{M}$ WIN 55,212-2), $1.3 \pm 0.5(1 \mu \mathrm{M})$, and $1.2 \pm 0.2 \%(0.1 \mu \mathrm{M}))$, increased the calcium current by $90.4 \pm 1.6(\mathrm{p}<0.0001), 84.3 \pm 1.7(\mathrm{p}<0.0001)$, and $50.4 \pm 2.9 \%$ $(\mathrm{p}<0.001)$, at concentrations of 10,1 , and $0.1 \mu \mathrm{M}$, respectively, when applied by itself ( $\mathrm{n}=3$ for each concentration) (Figure $2 \mathrm{~B}$ and 2D). Anandamide (0.1-10 mM), methanandamide (0.1-10 $\mu \mathrm{M})$, and AM251 (0.1-10 $\mu \mathrm{M})$ had no effects on uninjected neurons ( $\mathrm{n}=3$ for each drug). AM630, another cannabinoid antagonist, as well as blocking the effect of WIN 55,212-2 (the corresponding values being $1.1 \pm 0.2$ (10 mM WIN 55,212-2), $1.0 \pm 0.7(1 \mu \mathrm{M})$, and $1.4 \pm 0.3 \%(0.1 \mu \mathrm{M}))$, increased the calcium current just as AM251 did, when applied alone $(n=3$ for each concentration; Figure 2D). These results indicate that the cannabinoid antagonists AM251 and AM630 act as inverse agonists in this preparation, suggesting that some expressed cannabinoid receptors are in a constitutively active state, as previously described in this and other preparations. ${ }^{18-22}$ The above effects were all reversible.

\section{Effects of glutamatergic compounds}

In the present study, we tested the effects of two agonists of these receptors [L-CCG-I and DCG-IV, type 2 metabotropic 


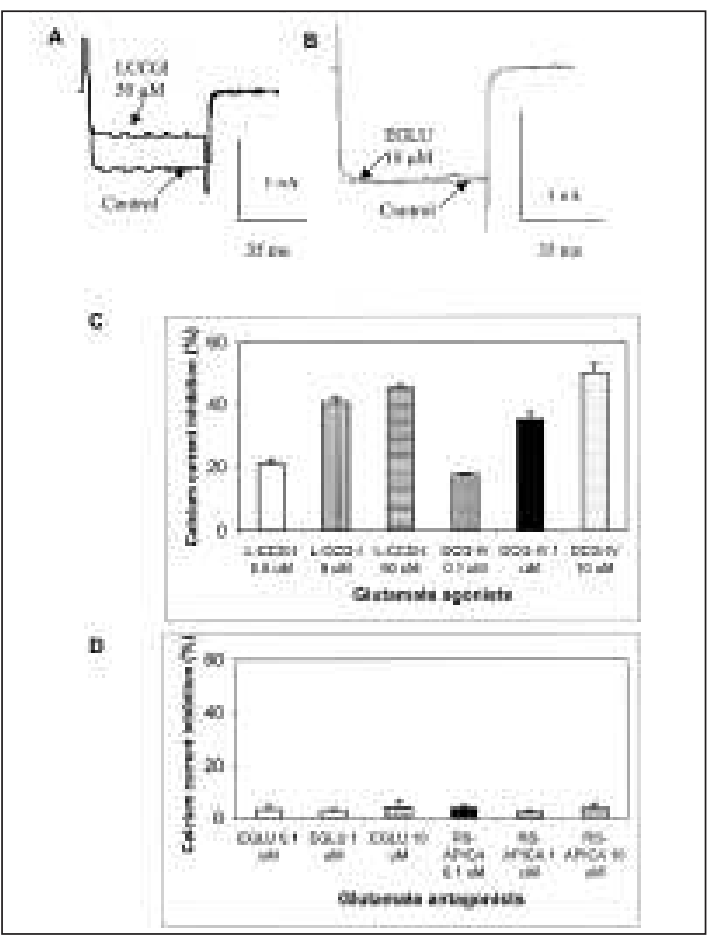

Figure 3: Effects of glutamate agonists and antagonists on $\mathrm{Ca}^{2+}$ current in sympathetic neurons. A) Superimposed traces of $\mathrm{Ca}^{2+}$ currents recorded from another SCG neuron (i. e., a different neuron from that in Fig. 1) in the absence (Control) and presence of L-CCG-I (50 $\mu M)$. Currents were induced by depolarizing voltage pulses from $-80 \mathrm{mV}$ to a test potential of $+5 \mathrm{mV}$. B) Superimposed traces of Ca2+ currents recorded from the same neuron as in $A$ ) in the absence (Control) and presence of EGLU (10 $\mu \mathrm{M} E G L U)$. C) Bar graph showing the $\mathrm{Ca}^{2+}$ current inhibition induced by all concentrations used of L-CCG-I and $D C G-I V$ (glutamate agonists). D) Bar graph showing the effects of EGLU and (RS)-APICA (glutamate antagonists). All data are from neurons microinjected with $m G l u R 2$ receptor $c D N A$.

glutamate receptor (mGluR2) agonists] on the calcium current (Figure 3A and 3C). At $50 \mu \mathrm{M}$, L-CCG-I decreased the calcium current by $45.5 \pm 0.8 \%(\mathrm{p}<0.0001, \mathrm{n}=3)$, at $5 \mu \mathrm{M}$ by $40.7 \pm 1.5 \%$ $(\mathrm{p}<0.0001, \mathrm{n}=3)$, and at $0.5 \mu \mathrm{M}$ by $20.9 \pm 1.8 \%(\mathrm{p}<0.005, \mathrm{n}=3)$ in microinjected neurons, but it had no effect in uninjected neurons. At $10 \mu \mathrm{M}$, DCG-IV decreased the calcium current by $50.4 \pm 2.9 \%$ $(\mathrm{p}<0.001, \mathrm{n}=3)$, at $1 \mu \mathrm{M}$ by $35.2 \pm 2.2 \%(\mathrm{p}<0.001, \mathrm{n}=3)$, and at $0.1 \mu \mathrm{M}$ by $17.5 \pm 0.5 \%(\mathrm{p}<0.005, \mathrm{n}=3)$ in microinjected neurons, but it too had no effect in uninjected neurons. EGLU and (RS)APICA, mGluR2 antagonists, blocked the effects of DCG-IV (the corresponding values being for EGLU 1.6 $\pm 0.2(10 \mu \mathrm{M})$, $2.1 \pm 0.4(1 \mu \mathrm{M})$, and $0.6 \pm 0.3 \%(0.1 \mu \mathrm{M})$ and for (RS)-APICA $1.3 \pm 0.1(10 \mu \mathrm{M}), 1.1 \pm 0.5(1 \mu \mathrm{M})$, and $1.6 \pm 0.7 \%(0.1 \mu \mathrm{M}))$. However, by themselves they had no effect on microinjected neurons at the concentrations used (Figure 3B and, 3D). They too had no effect on uninjected neurons. These results indicate that L-CCG-I and DCG-IV are adequate pharmacologic tools for investigations of the modulation of calcium channels via mGluR2 receptors.

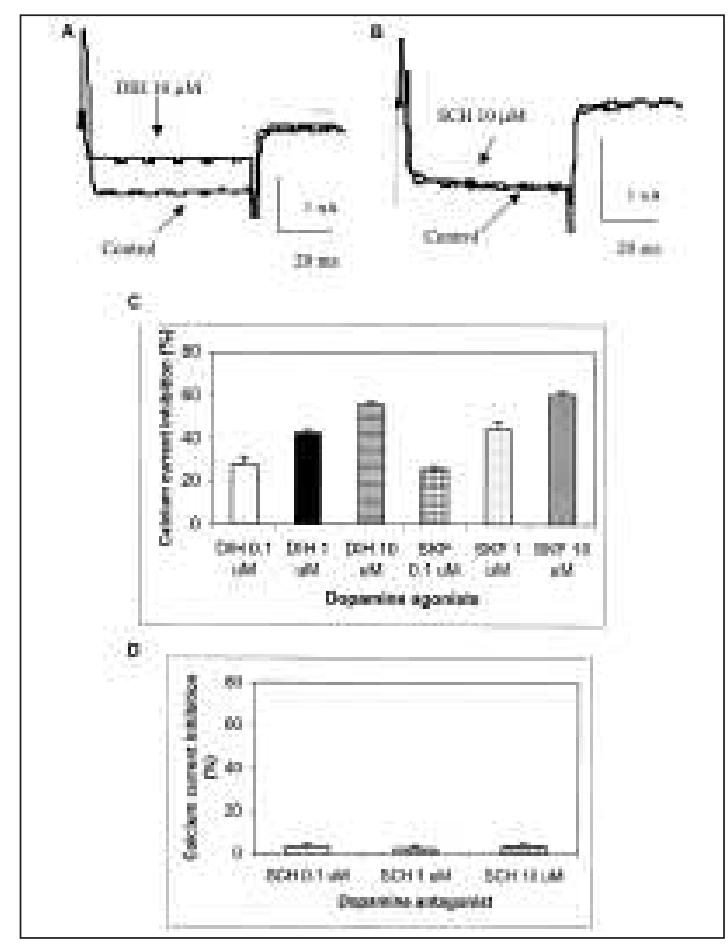

Figure 4: Effects of dopamine agonists and antagonists on $\mathrm{Ca}^{2+}$ current in sympathetic neurons. A) Superimposed traces of $\mathrm{Ca}^{2+}$ currents recorded from an SCG neuron in the absence (Control) and presence of dihydrexidine $(10 \mu \mathrm{M} D \mathrm{DH})$. The neuron was depolarized from a holding potential of $-80 \mathrm{mV}$ to a test potential of $+5 \mathrm{mV}$. B) Superimposed traces of $\mathrm{Ca}^{2+}$ currents recorded from an SCG neuron in the absence (Control) and presence of SCH-23390 (10 $\mu \mathrm{M} S \mathrm{SCH})$. Currents were induced by depolarizing voltage pulses from $-80 \mathrm{mV}$ to a test potential of $+5 \mathrm{mV}$. C) Summary of the effects of two dopamine agonists, DIH and SKF. D) Bar graph showing the effects of a dopamine antagonist, SCH (all concentrations used) on the $\mathrm{Ca}^{2+}$ current. All data are from SCG neurons microinjected with D1 receptor cDNA.

\section{Effects of dopaminergic compounds on $\mathrm{Ca}^{2+}$ currents in sympathetic neurons}

We tested the effects of dihydrexidine, SKF-38393, and SCH23390 on $\mathrm{Ca}^{2+}$ currents in sympathetic neurons microinjected with D1 receptor cDNA (Figure 4). Dihydrexidine, a dopamine D1 receptor agonist, reduced the calcium current by $55.5 \pm 1.3 \%$ $(\mathrm{p}<0.001), 42.4 \pm 1.2 \%(\mathrm{p}<0.0001)$, and $28.1 \pm 2.9 \%(\mathrm{p}<0.01)$ at concentrations of 10,1 , and $0.1 \mu \mathrm{M}$, respectively ( $\mathrm{n}=3$ for each concentration) (Figure 4A and 4C). SKF-38393, another dopamine D1 receptor agonist, inhibited the calcium current just as dihydrexidine did ( $\mathrm{n}=3$ for each concentration, Figure $4 \mathrm{C}$ ). By itself, the dopamine D1 receptor antagonist SCH-23390 had no effect on the calcium current (Figure 4B and 4C), but it blocked the above agonists' effects at concentrations within the range $0.1-10 \mu \mathrm{M}(\mathrm{n}=3$ for each concentration, the corresponding values being $1.4 \pm 0.8(10 \mu \mathrm{M}), 1.6 \pm 0.2(1 \mu \mathrm{M})$, and $0.9 \pm 0.5 \%$ $(0.1 \mu \mathrm{M})$. The above agents had no effects in uninjected neurons. 
Table 1: Comparison of the effects (percentage reduction in $\mathrm{Ca} 2+$ current) of a drug combination with the effects of the same concentrations of individual drugs (cannabinoids and glutamate agonists)

\begin{tabular}{c|c|c|c}
\hline WIN & L-CCG-I & WIN + \\
L-CCG-I & p* \\
\hline $40.1 \pm 1.7 \%(0.1 \mu \mathrm{M})$ & $20.9 \pm 1.8 \%(0.5 \mu \mathrm{M})$ & $20.1 \pm 1.8 \%(0.1+0.5 \mu \mathrm{M})$ & 0.21 \\
\hline $50.2 \pm 0.9 \%(1 \mu \mathrm{M})$ & $40.7 \pm 1.5 \%(5 \mu \mathrm{M})$ & $40.3 \pm 2.7 \%(1+5 \mu \mathrm{M})$ & 0.47 \\
\hline $60.7 \pm 1.2 \%(10 \mu \mathrm{M})$ & $45.5 \pm 0.8 \%(50 \mu \mathrm{M})$ & $50.2 \pm 2.9 \%(10+50 \mu \mathrm{M})$ & 0.24 \\
\hline
\end{tabular}

*p, ANOVA test

Table 2: Comparison of the effects (percentage reduction in $\mathrm{Ca}^{2+}$ current) of a drug combination with the effects of the same concentrations of individual drugs (cannabinoids and glutamate agonists)

\begin{tabular}{c|c|c|c}
\hline METHANANDAMIDE & DCG-IV & METHANANDAMIDE+ \\
\hline DCG-IV & p* \\
\hline $19.0 \pm 2.0 \%(0.1 \mu \mathrm{M})$ & $17.5 \pm 0.5 \%(0.1 \mu \mathrm{M})$ & $19.5 \pm 2.7 \%(0.1+0.1 \mu \mathrm{M})$ & 0.65 \\
\hline $45.4 \pm 1.6 \%(1 \mu \mathrm{M})$ & $35.2 \pm 2.2 \%(1 \mu \mathrm{M})$ & $38.5 \pm 2.1 \%(1+1 \mu \mathrm{M})$ & 0.19 \\
\hline $50.2 \pm 1.0 \%(10 \mu \mathrm{M})$ & $50.4 \pm 2.9 \%(10 \mu \mathrm{M})$ & $50.1 \pm 1.1 \%(10+10 \mu \mathrm{M})$ & 0.93 \\
\hline
\end{tabular}

*p, ANOVA test

\section{Combined effects of cannabinoids and glutamatergic compounds}

To explore the possible interactions between cannabinoid and glutamate receptors, we tested the effects of combined applications of agonists for these receptors. Application of the mGluR2 agonist L-CCG-I $(50 \mu \mathrm{M})$ plus the CB1 agonist WIN $55,212-2(10 \mu \mathrm{M})$ decreased the calcium current by $50.2 \pm 2.9 \%$ $(\mathrm{p}=0.003, \mathrm{n}=3)$ (Figure 5A and 5C), while with $5 \mu \mathrm{M}$ of L-CCGI plus $1 \mu \mathrm{M}$ of WIN 55,212-2 it was decreased by $40.3 \pm 2.7 \%$ $(\mathrm{p}<0.005, \mathrm{n}=3)$, and with $0.5 \mu \mathrm{M}$ of L-CCG-I plus $0.1 \mu \mathrm{M}$ of WIN $55,212-2$ by $20.1 \pm 1.8 \% \quad(p<0.005, n=3)$. Only those neurons microinjected were affected, not uninjected ones. Application of $0.5 \mu \mathrm{M}$ L-CCG-I plus $0.1 \mu \mathrm{M}$ of WIN 55,212-2 tended to have a weaker inhibitory effect than WIN alone; however, a comparison of the three groups revealed no significant difference among them (Table 1, top row). Likewise, combined application of the cannabinoid agonist methanandamide and the glutamate mGluR2 agonist DCG-IV produced no additional effect (Table 2 and Figure 5B and 5C). Again, these effects were seen only in microinjected neurons, not in uninjected ones.

\section{Combined effects of cannabinoids and dopaminergic compounds}

To explore the possible interactions between cannabinoid and dopamine receptors, we tested combined applications of agonists for these receptors. Application of the D1 agonist dihydrexidine $(10 \mu \mathrm{M})$ plus the CB1 agonist WIN 55,212-2 (10 $\mu \mathrm{M})$ decreased the calcium current by $100.6 \pm 0.9 \%(\mathrm{p}<0.0001, \mathrm{n}=3$ ) (Figure 6A and $6 \mathrm{C}), 1 \mu \mathrm{M}$ of each drug decreased it by $80.5 \pm 1.3 \%$ $(\mathrm{p}<0.0005, \mathrm{n}=3)$, and $0.1 \mu \mathrm{M}$ of each drug by $55.6 \pm 1.4 \%$ $(\mathrm{p}<0.0001, \mathrm{n}=3)$. Only those neurons microinjected were affected, not uninjected ones. Such combined applications had an additional effect (Table 3) over and above each of those seen when either drug was applied separately (e.g., compare data in Figures $2 \mathrm{C}$ and $4 \mathrm{C}$ with that in Figure $6 \mathrm{C}$ ). Likewise, combined application of the cannabinoid agonist methanandamide and the D1 dopamine agonist SKF-38393 (Table 4) produced an additional effect (compare data in Figures $2 \mathrm{C}$ and $4 \mathrm{C}$ with that in Figure 6C), again only in microinjected neurons, not in uninjected ones.

\section{DISCUSSION}

The main purpose of the present study was to characterize the combined effects of cannabinoids and glutamate- or dopaminereceptor agonists on the $\mathrm{Ca}^{2+}$-current in sympathetic neurons microinjected with the cDNAs for those receptors. We found that cannabinoids, and glutamate and dopamine agonists each inhibited the $\mathrm{Ca}^{2+}$ current when applied separately. In this respect, our results confirm similar effects described in neurons expressing these receptors or in heterologous expression systems $\mathrm{s}^{8-10}$, for cannabinoid receptors. In the case of dopamine receptors, Bigornia et $\mathrm{a}^{23}$ observed that dopamine D2 receptors reduced calcium channel currents. Moreover, in retinal horizontal cells dopamine has been reported reduce $\mathrm{T}$ calcium currents, ${ }^{24}$ while in adrenal glomerulosa cells the T-type $\mathrm{Ca}^{2+}$ 


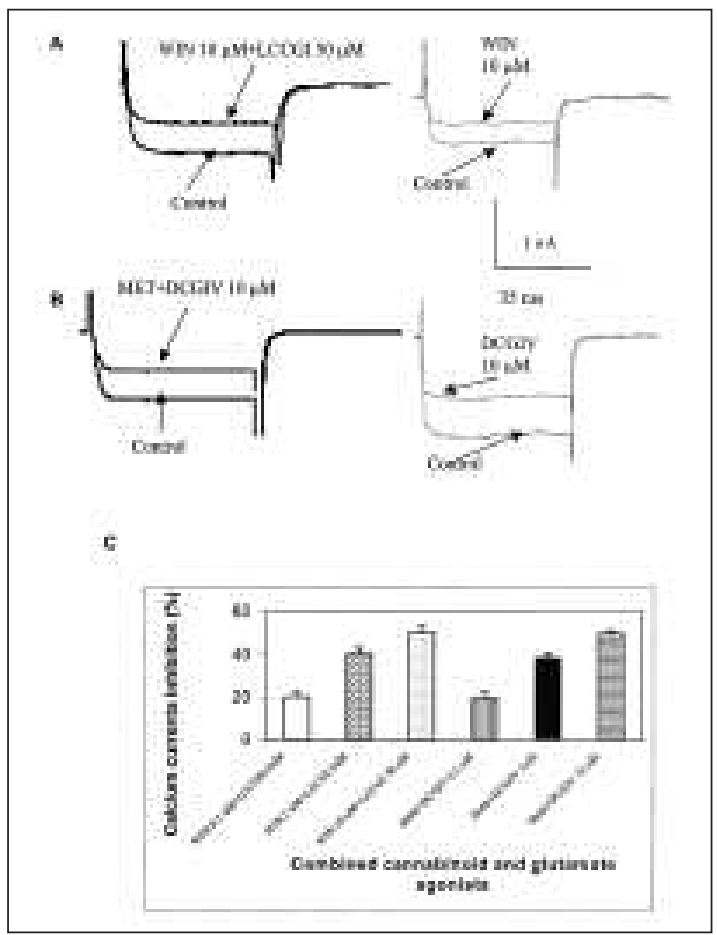

Figure 5: Combined effects of cannabinoid and glutamate agonists on $\mathrm{Ca}^{2+}$ current in sympathetic neurons. A) Left part, superimposed traces of $\mathrm{Ca}^{2+}$ currents recorded from an SCG neuron in the absence (Control) and presence of WIN 55,212-2 (10 $\mu \mathrm{M}$ WIN) plus L-CCG-I (50 $\mu \mathrm{M}$ LCCGI). Right part, superimposed traces of $\mathrm{Ca}^{2+}$ currents in the presence of a single agonist (WIN 55,212-2 (10 $\mu \mathrm{M}$ WIN)). The neurons were depolarized from a holding potential of $-80 \mathrm{mV}$ to a test potential of $+5 \mathrm{mV}$. B) Left part, superimposed traces of $\mathrm{Ca}^{2+}$ currents recorded from an SCG neuron in the absence (Control) and presence of methanandamide (10 $\mu \mathrm{M}$ METHAN) plus DCG-IV (10 $\mu M$ DCGIV). Right part, superimposed traces of $\mathrm{Ca}^{2+}$ currents in the presence of a single agonist (DCG-IV (10 $\mu M$ DCGIV)).Currents were induced by depolarizing voltage pulses from $-80 \mathrm{mV}$ to a test potential of $+5 \mathrm{mV}$. C) Summary of the effects on $\mathrm{Ca}^{2+}$ currents induced by combined application of all the concentrations used of cannabinoid and glutamate agonists. All data are from SCG neurons microinjected with cDNAs for human cannabinoid CB1 and mGluR2 receptors.

current has been found to be blocked by activation of the D2 receptor. ${ }^{25}$ In addition, D1 receptor activation inhibits $\mathrm{Ca}^{2+}$ currents ( $\mathrm{N}$ - and P-types) (in striatal neurons ${ }^{26}$ ), and it has been demonstrated that in rat adrenal glomerulosa cells, D1 inhibition is mediated by the Gs-coupling $G$ protein (through its $\beta \gamma$ subunit) and an increase in the cAMP concentration. ${ }^{27}$ On the other hand, glutamate has been found to inhibit the N-type $\mathrm{Ca}^{2+}$ current in sympathetic neurons microinjected with the cDNA for the mGluR2 receptor, ${ }^{28}$ while group II mGlu receptor agonists inhibit voltage-gated $\mathrm{Ca}^{2+}$ channels in the rat cerebellum, ${ }^{29}$ and activation of the group II mGlu receptor inhibits voltage-gated $\mathrm{Ca}^{2+}$ channels in myenteric neurons. ${ }^{30}$ Thus, the cellular mechanism by which $\mathrm{CB} 1$, mGluR2, and D1 receptors modulate the $\mathrm{Ca}^{2+}$ channels in sympathetic neurons microinjected with the cDNAs for these receptors would appear to be by activation of the pertussis toxin-sensitive $\mathrm{G}$ protein pathway involving the $\mathrm{Gi}$ family (such as $\mathrm{G}_{\mathrm{i}}$ or $\mathrm{G}_{\mathrm{o}}$ ) and the $\mathrm{G}_{\mathrm{s}}$-coupling $\mathrm{G}$ protein, through

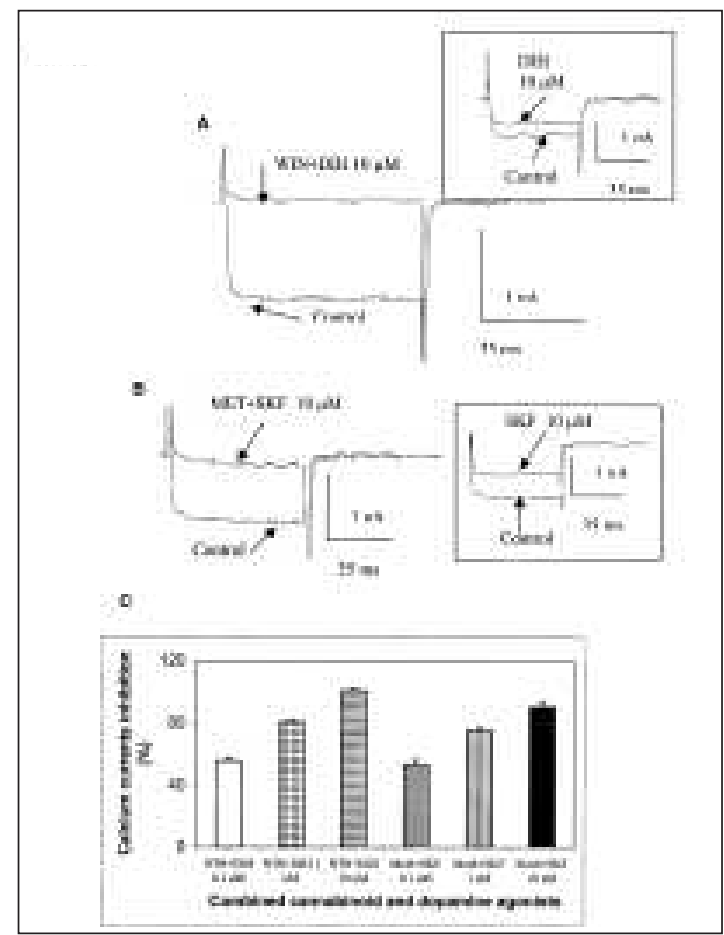

Figure 6: Combined effects of cannabinoid and dopamine agonists on $\mathrm{Ca}^{2+}$ current in sympathetic neurons. A) Superimposed traces of $\mathrm{Ca}^{2+}$ currents recorded from an SCG neuron in the absence (Control) and presence of WIN 55,212-2 (10 $\mathrm{MM}$ WIN) plus dihydrexidine $(10 \mu \mathrm{M}$ $D I H)$. Inset, superimposed traces of $\mathrm{Ca}^{2+}$ currents in the presence of a single agonist (DIH $(10 \mu \mathrm{M} D I H))$. The neurons were depolarized from a holding potential of $-80 \mathrm{mV}$ to a test potential of $+5 \mathrm{mV}$. B) Superimposed traces of $\mathrm{Ca}^{2+}$ currents recorded from an SCG neuron in the absence (Control) and presence of methanandamide (10 $\mu \mathrm{M}$ METHAN) plus SKF-38393 (10 $\mu M$ SKF). Inset, superimposed traces of $\mathrm{Ca}^{2+}$ currents in the presence of a single agonist (SKF (10 $\left.\mu M S K F\right)$ ). Currents were induced by depolarizing voltage pulses from $-80 \mathrm{mV}$ to a test potential of $+5 \mathrm{mV}$. C) Summary of the effects on the Ca ${ }^{2+}$ currents induced by combined application of all the concentrations used of cannabinoid and dopamine agonists. All data are from SCG neurons microinjected with cDNAs for human cannabinoid CB1 and D1 receptors.

its $\beta \gamma$-subunit. ${ }^{8-10,27,30}$ Inhibition of these $\mathrm{Ca}^{2+}$ channels would be expected to decrease the likelihood both of neurotransmitter release and of successful synaptic transmission, and also to suppress other calcium-dependent processes in these cells. An important functional insight would be obtained if we were able to establish the type of $\mathrm{Ca}^{2+}$ channels affected by this synergism. This might be achieved using a specific voltage-command protocol and/or a pharmacological solution for each voltagedependent calcium channel. We suggest that the N-type may be the channel involved in our preparation because: 1) the voltage command (amplitude and duration) used in our experiment is specific for activating $\mathrm{N}$-type $\mathrm{Ca}^{2+}$ channels, 2) $80-85 \%$ of the whole-cell peak current in these cells is carried through $\mathrm{N}$-type $\mathrm{Ca}^{2+}$ channels, and 3) previous reports have indicated that CB1 and D1 receptors inhibit $\mathrm{N}$-or T-type $\mathrm{Ca}^{2+}$ channels, and SCG neurons do not have T-type $\mathrm{Ca}^{2+}$ channels. ${ }^{8-10,23-27,31-33}$

The behavior of over-expressed receptors not normally 
Table 3: Comparison of the effects (percentage reduction in $\mathrm{Ca}^{2+}$ current) of a drug combination with the effects of the same concentrations of individual drugs (cannabinoids and dopamine agonists)

\begin{tabular}{c|c|c|c}
\hline WIN & DIHYDREXIDINE & WIN + DIHYDREXIDINE & p* \\
\hline $40.1 \pm 1.7 \%(0.1 \mu \mathrm{M})$ & $28.1 \pm 2.9 \%(0.1 \mu \mathrm{M})$ & $55.6 \pm 1.4 \%(0.1+0.1 \mu \mathrm{M})$ & $<0.005$ \\
\hline $50.2 \pm 1.0 \%(1 \mu \mathrm{M})$ & $42.4 \pm 1.2 \%(1 \mu \mathrm{M})$ & $80.5 \pm 1.3 \%(1+1 \mu \mathrm{M})$ & $<0.001$ \\
\hline $60.7 \pm 1.2 \%(10 \mu \mathrm{M})$ & $55.5 \pm 1.3 \%(10 \mu \mathrm{M})$ & $100.6 \pm 0.9 \%(10+10 \mu \mathrm{M})$ & $<0.0001<$ \\
\hline
\end{tabular}

*p, ANOVA test

Table 4: Comparison of the effects (percentage reduction in $\mathrm{Ca}^{2+}$ current) of a drug combination with the effects of the same concentrations of individual drugs (cannabinoids and dopamine agonists)

\begin{tabular}{c|c|c|c}
\hline METHANANDAMIDE & SKF & METHANANDAMIDE+ \\
SKF & p* \\
\hline $29.0 \pm 2.0 \%(0.1 \mu \mathrm{M})$ & $25.6 \pm 1.4 \%(0.1 \mu \mathrm{M})$ & $53.4 \pm 2.7 \%(0.1+0.1 \mu \mathrm{M})$ & $<0.005$ \\
\hline $45.4 \pm 1.6 \%(1 \mu \mathrm{M})$ & $44.3 \pm 3.4 \%(1 \mu \mathrm{M})$ & $75.3 \pm 1.3 \%(1+1 \mu \mathrm{M})$ & $<0.005$ \\
\hline $53.0 \pm 1.5 \%(10 \mu \mathrm{M})$ & $60.2 \pm 1.9 \%(10 \mu \mathrm{M})$ & $90.1 \pm 2.4 \%(10+10 \mu \mathrm{M})$ & $<0.005$ \\
\hline
\end{tabular}

*p, ANOVA test

present in the cell-type being examined and the use of a heterologous expression system instead of physiological neuronal/glial environments could be said to be limitations of our observations. However, although the density of receptors expressed in SCG neurons in our study is unknown, Landsman et $\mathrm{al}^{20}$ reported transfected cells expressing $2.6 \mathrm{pmol} / \mathrm{mg}$ protein $\mathrm{hCB} 1$ receptors, while in vivo the $\mathrm{CB} 1$ cannabinoid receptors density is $6.3 \mathrm{pmol} / \mathrm{mg}$ protein in the rat substantia nigra and 4.1 $\mathrm{pmol} / \mathrm{mg}$ in the hippocampal dentate gyrus molecular layer. ${ }^{34}$ Thus, there are brain areas with physiologically high expression levels of these receptors. Further, there are brain areas that physiologically co-express dopamine and cannabinoid receptors (striatal neurons, globus pallidus, substantia nigra ${ }^{14,35,36}$ ) and areas that physiologically co-express glutamate and cannabinoid receptors (cerebral cortex and thermosensitive regions of the hypothalamus $\left.{ }^{15,37,38}\right)$. It remains possible that the expression of receptors in central neurons might differ from those in our experimental conditions to such an extent that cooperativity between receptors occurs either not occur at all or at least not to the same extent.

It has previously been reported that SR141716A, a cannabinoid antagonist, acts as an inverse agonist on hCB1 receptors. ${ }^{19-22}$ The authors suggested that cannabinoid receptors are in a constitutively active state. When we tested two other cannabinoid antagonists, AM251 and AM630, each of which has also been demonstrated to act as an inverse agonist, ${ }^{39,40}$ we found evidence that they act as inverse agonists in SCG neurons expressing hCB1 cannabinoid receptors (viz. when applied by themselves, they altered ionic currents). These effects were the opposite of those induced by the cannabinoid agonists. For an cannabinoid antagonist to have an effect, some receptors must be in an active state. The active state of the receptor could arise through two different mechanisms: 1) activation by an endogenous agonist, or 2) adoption of a spontaneously active state. In the former case, the effect of a cannabinoid antagonist would be that of a classical antagonist, whereas in the latter case the cannabinoid antagonist would be acting as an inverse agonist, as in the present study. To account for the phenomenon of inverse agonism, a two-state receptor model has been proposed. In this model, receptors exist in an equilibrium between inactive $(R)$ and active $\left(\mathrm{R}^{*}\right)$ states. Agonists stabilize the $\mathrm{R}^{*}$ state, inverse agonists stabilize the $\mathrm{R}$ state, and antagonists have equal preferences for both states. ${ }^{41-43}$ Thus, for an antagonist to be an inverse agonist some receptors must be in the active $\mathrm{R} *$ state. $^{19-22}$

In the present study, we found that the responses elicited by co-application of cannabinoid and glutamate agonists were no greater than either of the responses obtained by individual application of one of the agonists. These data indicate that these cannabinoid and glutamate agonists activate a common set of $\mathrm{Ca}^{2+}$ channels in SCG neurons microinjected with $\mathrm{CB} 1$ and mGluR2 cDNAs, probably because both receptors use the same $\mathrm{G}_{\mathrm{i} / \mathrm{o}}$ proteins. ${ }^{8-10,28}$ This absence of an interaction between cannabinoid and glutamate receptors could be important in determining the strength of neurotransmission at synapses at which anandamide and glutamate are co-transmitters. In this 
regard, there are in vivo and in vitro findings suggesting an increase in cortical glutamatergic transmission via CB1 receptors, ${ }^{37}$ and there is recent evidence to suggest (a) that interactions between NMDA and $\mathrm{CB} 1$ receptors lead to synergistic hypothermia, ${ }^{15}$ and (b) that there are direct and indirect interactions between the $\mathrm{CB} 1$ receptor and the group II metabotropic glutamate receptor in the rat prefrontal cortex. ${ }^{38}$ The nature of any functional interaction between cannabinoid and glutamate receptors may also depend on the specific expression of these receptors, as earlier suggested for the subunit composition of nicotinic cholinergic and $\mathrm{P} 2 \mathrm{X}$ purine receptors. ${ }^{44}$

The cooperativity we observed in respect of $\mathrm{Ca}^{2+}$ current inhibition when cannabinoid and dopamine agonists were applied together indicates interactions at some level in their signaling pathways. Most likely, individual $\mathrm{Ca}^{2+}$ channels require the binding of multiple $\beta \gamma$ subunits, and individual $\mathrm{Ca}^{2+}$ channels share a pool of G-proteins that can be activated by multiple receptors. Another possibility is that the two receptors use different $G$ proteins (cannabinoid receptors $\mathrm{G}_{\mathrm{i} / \mathrm{o}}$, dopamine receptors $\mathrm{G}_{\mathrm{s}}$ ), ${ }^{8-10,45}$ even though it has been reported that cannabinoid receptors can couple to both $\mathrm{G}$ proteins. ${ }^{14}$ Whatever its molecular basis, this cooperativity may be significant physiologically, the basal extracellular levels of these transmitters within some nervous system regions perhaps being high enough to produce $\mathrm{Ca}^{2+}$ current inhibition in neurons in those regions. Such effects would be enhanced by cooperativity among the actions of multiple transmitters. This raises the possibility of interactions between hormones and neurotransmitters coupled to G-protein receptors in the control of neurotransmitter secretion by neurons. In this regard, there is interesting experimental evidence of interactions between cannabinoid and dopaminergic systems: (a) a predominant role for dopamine D1 receptors in the regulation of the cataleptic response to cannabinoids has been found; ${ }^{46}$ (b) a concurrent stimulation of cannabinoid CB1 and dopamine D2 receptors has been observed to augment cAMP accumulation in striatal neurons $;{ }^{14}$ (c) D2 receptors may have a significant modulatory role in determining the $\mathrm{G}$ protein coupling specificity of $\mathrm{CB} 1$ receptors ${ }^{47}$ and (d) interactions have been described between cannabinoids and the dopaminergic system with effects on rotational behavior in rats. ${ }^{35,36,48}$ Additionally, there are results suggesting that functional interactions between endocannabinoid and dopaminergic systems may contribute to striatal signaling. ${ }^{49}$ This cooperativity indicates that there is some type of interaction, most likely via release of endogenous ligands, on application of such drug combinations. ${ }^{50}$ Further study will be required to confirm or deny this. The micromolar concentrations of ligands that are needed to show cooperative activity raise questions about the specificity of these drugs. However, those are the concentrations used in all previous reports of these various receptors, and at these micromolar concentrations glutamate agonists induced no detectable effects. On the other hand, non additive effects have been observed with high concentrations of cannabinoid and dopamine agonists. ${ }^{51}$ Additionally, a recent report that utilized concurrent activation of dopamine and cannabinoid receptors employed concentrations in the micromolar range. ${ }^{45}$

To the best of our knowledge, this is the first reported example of an interaction between cannabinoid and dopamine receptors on ionic currents, specifically a $\mathrm{Ca}^{2+}$ current, indicating that receptor interactions within the nervous system may be important events in the regulation of the functions of ionic channels.

\section{ACKNOWLEDGEMENTS}

This work was supported by a grant J34532 from CONACyTMexico to Dr. C.V.

\section{REFERENCES}

1. Matsuda LA, Lolait SJ, Brownstein MJ, Young AC, Bonner TI. Structure of a cannabinoid receptor and functional expression of the cloned cDNA. Nature 1990; 346: 561-564.

2. Gifford AN, Ashby CR. Electrically evoked acetylcholine release from hippocampal slices is inhibited by the cannabinoid receptor agonist, WIN 55212-2, and is potentiated by the cannabinoid antagonist, SR 141716A. J Pharmacol Exp Ther 1996; 277: 14311436.

3. Katona I, Sperlágh B, Sík A, et al. Presynaptically located CB1 cannabinoid receptors regulate GABA release from axon terminals of specific hippocampal interneurons. J Neurosci 1999; 19: 4544-4558

4. Hoffman AF, Lupica CR. Mechanisms of cannabinoid inhibition of GABA(A) synaptic transmission in the hippocampus. J Neurosci 2000; 20: 2470-2479.

5. Kathmann M, Bauer U, Schlicker E, Gothert M. Cannabinoid CB1 receptor-mediated inhibition of NMDA- and kainate-stimulated noradrenaline and dopamine release in the brain. NaunynSchmiedeberg's Arch Pharmacol 1999; 359: 466-470.

6. Nakazi M, Bauer U, Nickel T, Kathmann M, Schlicker E. Inhibition of serotonin release in the mouse brain via presynaptic cannabinoid CB1 receptors. Naunyn-Schmiedeberg's Arch Pharmacol 2000; 361: 19-24.

7. Kim DJ, Thayer SA. Activation of CB1 cannabinoid receptors inhibits neurotransmitter release from identified synaptic sites in rat hippocampal cultures. Brain Res 2000; 852: 398-405.

8. Pan X, Ikeda SR, Lewis DL. Rat brain cannabinoid receptor modulates N-type $\mathrm{Ca}^{2+}$ channels in a neuronal expression system. Mol Pharmacol 1996; 49: 707-714.

9. Twitchell W, Brown S, Mackie K. Cannabinoids inhibit N- and P/Qtype calcium channels in cultured rat hippocampal neurons. J Neurophysiol 1997; 78: 43-50.

10. Mackie K, Lai Y, Westenbroek R, Mitchell R. Cannabinoids activate an inwardly rectifying potassium conductance and inhibit Q-type calcium currents in AtT20 cells transfected with rat brain cannabinoid receptor. J Neurosci 1995; 15: 6552-6561.

11. Schweitzer P. Cannabinoids decrease the $\mathrm{K}^{+} \mathrm{M}$-current in hippocampal CA1 neurons. J Neurosci 2000; 20: 51-58.

12. Bidaut-Rusell M, Howlett A. Cannabinoid receptor-regulated cyclic AMP accumulation in the rat striatum. J Neurochem 1991; 57 : 1769-1773.

13. Glass M, Brotchie JM, Maneuf YP. Modulation of neurotransmission by cannabinoids in the basal ganglia. Eur J Neurosci 1997; 9: 199-203.

14. Glass M, Felder CC. Concurrent stimulation of cannabinoid CB1 and dopamine D2 receptors augments cAMP accumulation in striatal neurons: evidence for a Gs linkage to the CB1 receptor. J Neurosci 1997; 17: 5327-5333.

15. Rawls SM, Cowan A, Tallarida RJ, Geller EB, Adler MV. N-methylD-aspartate antagonists and WIN 55212-2 [4,5-dihydro-2methyl-4(4-morpholinylmethyl)-1(1-naphthalenyl-carbonyl)-6H pyrrolo[3,2,1i,j]quinolin-6-one] a cannabinoid agonist, interact to produce synergistic hypothermia. J Pharmacol Exp Ther 2002; 303: 395-402.

16. Doherty J, Dingledine R. Functional interactions between cannabinoid and metabotropic glutamate receptors in the central nervous system. Curr Opin Pharmacol 2003; 3: 46-53.

17. Hamill OP, Marty A, Neher E, Sakmann B, Sigworth FJ. Improved patch-clamp techniques for high-resolution current recording 
from cells and cell-free membrane patches. Pflügers Arch 1981; 391: 85-100.

18. Pan X, Ikeda SR, Lewis DL. SR 141716 A acts as an inverse agonist to increase neuronal voltage-dependent $\mathrm{Ca}^{2+}$ currents by reversal of tonic CB1 cannabinoid receptor activity. Mol Pharmacol 1998; 54: 1064-1072.

19. Bouaboula M, Perrachon S, Milligan L, et al. A selective inverse agonist for central cannabinoid receptor inhibits mitogenactivated protein kinase activation stimulated by insulin or insulin-like growth factor 1 . Evidence for a new model of receptor/ligand interactions. J Biol Chem 1997; 272: 2233022339.

20. Landsman RS, Burkey TH, Consroe P, Roeske WR, Yamamura HI. SR 141716A is an inverse agonist at the human cannabinoid CB1 receptor. Eur J Pharmacol 1997; 334: R1-R2.

21. MacLennan SJ, Reynen PH, Kwan J, Bonhaus DW. Evidence for inverse agonism of SR 141716A at human recombinant cannabinoid CB1 and CB2 receptors. Br J Pharmacol 1998; 124: 619-622.

22. McAllister SD, Griffin G, Satin LS, Abood ME. Cannabinoid receptors can activate and inhibit $G$ protein-coupled inwardly rectifying potassium channels in a xenopus oocyte expression system. J Pharmacol Exp Ther 1999; 291: 618-626.

23. Bigornia L, Allen CN, Jan CR, et al. D2 dopamine receptors modulate calcium channel currents and catecholamine secretion in bovine adrenal chromaffin cells. J Pharmacol Exp Ther 1990; 252: 586-592.

24. Pfeiffer-Linn C, Lasater EM. Dopamine modulates in a differential fashion T and L-type calcium currents in bass retinal horizontal cells. J Gen Physiol 1993; 102: 277-294.

25. Osipenko ON, Varnai O, Mike A, Spät A, Bici E. Dopamine blocks T-type calcium channels in cultured rat adrenal glomerulosa cells. Endocrinology 1994; 134: 511-514.

26. Surmeier DJ, Bargas J, Hemmings HC Jr, Nairn AC, Greengard P. Modulation of calcium currents by a D1 dopaminergic protein kinase/phosphatase cascade in rat neostriatal neurons. Neuron 1995; 14: 385-397.

27. Drolet P, Bilodeau L, Chorvatova A, et al. Inhibition of the T-type $\mathrm{Ca}^{2+}$ current by the dopamine D1 receptor in rat adrenal glomerulosa cells: requirement of the combined action of the $G \beta \gamma$ protein subunit and cyclic adenosine $3^{\prime}, 5^{\prime}$-monophosphate. Mol Endocrinol 1997; 11: 503-514.

28. Ikeda SR, Lovinger DM, McCool BA, Lewis DL. Heterologous expression of metabotropic glutamate receptors in adult rat sympathetic neurons: subtype-specific coupling to ion channels. Neuron 1995; 14: 1029-1038.

29. Knoflach F, Woltering T, Adam G, Mutel V, Kemp JA. Pharmacological properties of native metabotropic glutamate receptors in freshly dissociated Golgi cells of the rat cerebellum. Neuropharmacology 2001; 40: 163-169.

30. Chen WP, Kirchgessner AL. Activation of group II mGlu receptors inhibits voltage-gated $\mathrm{Ca}^{2+}$ currents in myenteric neurons. Am J Physiol Gastrointest Liver Physiol 2002; 283: G1282-G1289.

31. Plummer MR, Logothetis DE, Hess P. Elementary properties and pharmacological sensitivities of calcium channels in mammalian peripheral neurons. Neuron 1989; 2: 1453-1463.

32. Ikeda SR. Double-pulse calcium channel current facilitation in adult rat sympathetic neurons. J Physiol 1991; 439: 181-214.

33. Barret CF, Rittenhouse AR. Modulation of N-type calcium channel activity by G-proteins and protein kinase C. J Gen Physiol 2000; 115: 277-286

34. Herkenham M, Lynn AB, Johnson MR, et al. Characterization and localization of cannabinoid receptors in rat brain: a quantitative in vitro autoradiographic study. J Neurosci 1991; 11: 563-583.
35. Sanudo-Pena MC, Walker JM. Effects of intrapallidal cannabinoids on rotational behavior in rats: interactions with the dopaminergic system. Synapse 1998; 28: 27-32.

36. Sanudo-Pena MC, Patrick SL, Patrick RL, Walker JM. Effects of intranigral cannabinoids on rotational behavior in rats: interactions with the dopaminergic system. Neurosci Lett 1996; 206: 21-24.

37. Ferraro L, Tomasini MC, Gessa GL, et al. The cannabinoid receptor agonist WIN 55,212-2 regulates glutamate transmission in rat cerebral cortex: an in vivo and in vitro study. Cereb Cortex 2001; 11: 728-733.

38. Barbara JG, Auclair N, Roisin MP, et al. Direct and indirect interactions between cannabinoid CB1 receptor and group II metabotropic glutamate receptor signaling in layer $\mathrm{V}$ pyramidal neurons from the rat prefrontal cortex. Eur J Neurosci 2003; 17 : 981-990.

39. Pertwee R, Griffin G, Fernando S. AM630, a competitive cannabinoid receptor antagonist. Life Sci 1995; 56: 1949-1955.

40. Ross RA, Brockie HC, Stevenson, LA, et al. Agonist-inverse agonist characterization at $\mathrm{CB} 1$ and $\mathrm{CB} 2$ cannabinoid receptors of L759633, L759656, and AM630. Br J Pharmacol 1999; 126: 665-672.

41. Costa T, Ogino Y, Munson PJ, Onaran HO, Rodbard D. Drug efficacy at guanine nucleotide-binding regulatory protein-linked receptors: thermodynamic interpretation of negative antagonism and of receptor activity in the absence of ligand. Mol Pharmacol 1992; 41: 549-560.

42. Chidiac P, Hebert TE, Valiquette M, Dennis M, Bouvier M. Inverse agonist activity of $\beta$-adrenergic antagonists. Mol Pharmacol 1994; 45: 490-499.

43. Samama P, Pei G, Costa T, Cotecchia S, Lefkowitz RJ. Negative antagonists promote an inactive conformation of the $\beta 2$ adrenergic receptor. Mol Pharmacol 1994; 45: 390-394.

44. Zhou X, Galligan JJ. Non-additive interaction between nicotinic cholinergic and $\mathrm{P} 2 \mathrm{X}$ purine receptors in guinea-pig enteric neurons in culture. J Physiol 1998; 513: 685-697.

45. Schiffmann SN, Lledo P-M, Vincent J-D: Dopamine D1 receptor modulates the voltage gated sodium current in rat striatal neurons through a protein kinase A. J Physiol 1995; 483: 95-107.

46. Rodriguez de Fonseca F, Martin Calderon JL, Mechoulam R, Navarro M. Repeated stimulation of D1 dopamine receptors enhances (-)-11-hydroxy-delta8-tetrahydrocannabinol-dimethylheptyl-induced catalepsy in male rats. Neuroreport 1994; 5: 761765.

47. Jarrahian A, Watts VJ, Barker EL. D2 dopamine receptors modulate G $\alpha$-subunit coupling of the CB1 cannabinoid receptor. J Pharmacol Exp Ther 2004; 308: 880-886.

48. Sanudo-Pena MC, Force M, Tsou K, Miller AS, Walker JM. Effects of intrastriatal cannabinoids on rotational behavior in rats: interactions with the dopaminergic system. Synapse 1998; 30: 221-226.

49. Giuffrida A, Parsons LH, Kerr TM, et al. Dopamine activation of endogenous cannabinoid signaling in dorsal striatum. Nat Neurosci 1999; 2: 358-363.

50. Cichewicz DL, Martin ZL, Smith FL, Welch SP. Enhancement of $\mu$ opioid antinociception by oral $\Delta^{9}$-tetrahydrocannabinol: doseresponse analysis and receptor identification. J Pharmacol Exp Ther 1999; 289: 859-867.

51. Fan SF, Yazulla S. Inhibitory interaction of cannabinoid CB1 receptor and dopamine D2 receptor agonists on voltage-gated currents of goldfish cones. Vis Neurosci 2004; 21: 69-77. 